\title{
Hominem quaerere. Człowiek w źródle historycznym, Jugowice, 26-29 maja 2004 r. Ad fontes. Interdyscyplinarne spotkania historyczne
}

Ogromna pokusą dla uczonych zajmujacych się badaniem przeszłości jest często formułowanie teorii "jak było" opierajac się tylko na własnych przekonaniach lub na poglądach utrwalonych w historiografii. Stąd też ogromnie pożyteczną wydaje się idea organizowania cyklicznie odbywających się pod hasłem ad fontes! spotkań historycznych, których organizatorami sa wrocławscy historycy Stanisław Rosik i Przemysław Wiszewski. Pod koniec maja 2004 w pięknej scenerii Jugowic koło Jedliny Zdroju odbyła się już piąta konferencja z tego cyklu. Tym razem jej hasłem przewodnim stało się poszukiwanie człowieka w źródłe historycznym. Uczestnicy konferencji zorganizowanej przez Instytut Historyczny Uniwersytetu Wrocławskiego byli przedstawicielami różnych dyscyplin historycznych, stąd też ,interdyscyplinarność" tematyki wystapień nie była tylko pustym sloganem. Różnorodność zapatrywań i metod pracy nad źródlem powoduje, o czym jestem przekonany, dużą wartosć merytoryczna sympozjum.

Obrady rozpoczęło wystapienie przedstawicieli władz Uniwersytetu Wrocławskiego, a przewodniczył im prof. Lech Leciejewicz (Warszawa). Pierwszy cykl referatów zebrany został przez organizatorów pod hasłem Homo historicus i poświęcony zostal archeologii. Prof. Bogusław Gediga (Wroclaw) przedstawił poczatki sztuki pradziejowej. Prof. Danuta Minta-Tworzowska (Poznań) przedstawiła następnie swe zapatrywania w kwestii powiązań źródeł archeologicznych i źródel historycznych, zauważając przy tym liczne sprzeczności między nimi. Podobna była też tematyka referatów dr Andrzeja Mierzwińskiego (Wrocław) i dr Ewy Wielgosz-Skorupki (Poznań). Następnie do dyskusji włączyli się antropolodzy i etnografowie: prof. Kazimiera Mikoś (Kraków) omówiła antropologiczny aspekt „Eddy poetyckiej” a prof. Leszek Słupecki (Warszawa) w nieszablonowy sposób podszedł do tematu kobiety - kochanki jako fundamentu ładu społecznego. Pierwszą część obrad zakończyły referaty oparte na analizie źródeł pisanych: dr Wojciech Baran-Kozlowski (Poznań) zajął się analizą „Kroniki swiata” Mariana Szkota, natomiast mgr Marcin Stabrowski (Wrocław) zaprezentował referat pt.: „Człowiek czy osoba, czyli o przedmiocie historii kultury na podstawie jednego akapitu z Pamiętników J. Ch. Paska”.

Hic homo to hasło drugiej części obrad, odbywającej się pod przewodnictwem prof. Krzysztofa Wachowskiego (Wrocław), którą rozpoczęlo wystąpienie prof. Przemysława Urbańczyka (PAN Warszawa), „tropiącego" pierwszego Islandczyka. Z kolei prof. Władysław Duczko (Uppsala) na przykładzie poszukiwań grobu św. Eryka zastanawiał się w referacie pt. „Znaleźć człowieka w nagich szkieletach i rozbitych gamkach" nad stosunkiem archeologów do specyfiki opracowywanego przez nich materiału źródłowego. Dr Maciej Michalski (Poznań) omówił następnie podłoże źródłowe sporu na temat św. Stanisława. Bohater jednostkowy był tematem kolejnych wystapień - dr Stanislaw Rosik (Wrocław) przedstawil obraz Wichmana utrwalony w „Dziejach Sasów” Widukinda z Korwei, natomiast dr Edward Skibiński (Poznań) zajął się dziełem Kosmasa z Pragi oraz mitami i faktami z nim zwiazanymi. Ostatnim referatem z tego cyklu stało się wystapienie dr Roberta Kołodzieja (Wroclaw) na temat sposobu ukazania hetmana Stanisława Koniecpolskiego przez autorów diariuszy sejmowych w czasach Władysława IV.

Bardzo ciekawy wątek przedstawienia nieznanego przez europejskich kronikarzy i podróżników ( Na styku światów) stał się mottem kolejnych wystąpień. Mgr Anna Prochowska-Sularz (Kraków) mówila o obrazie Germanów w korespondencji Wynfretha-Bonifacego, dr Małgorzata Ewa Kowalczyk (Wrocław) przedstawila sposób klasyfikacji ras ludzkich w działach geografów polskich XVIII w., natomiast mgr Anna Czyż (Wrocław) zajęła się Pierre-Esprit Radissonem i jego relacjami z Nowej Francji. 
Nad rolą źródła historycznego w kreowaniu rzeczywistości historiograficznej (Hominem crerare) zastanawiali się natomiast kolejni mówcy. Prof. Marek Cetwiński (Częstochowa) zajał się autobiograficznymi wstawkami w kronikach Galla Anonima i Janka z Czarnkowa, z kolei dr Piotr Boroń (Katowice) omówił na podstawie „Księgi Henrykowskiej” opisy bohaterów wypowiedziane przez opata Piotra. Dwa kolejne wystąpienia miały bardziej ogólny charakter. Dr Lucyna Harc (Wrocław) w referacie pt. „Od biogramu do biografii” zaprezentowała rozwój historyczny biografistyki, a dr Jacek Dębicki (Wrocław) przybliżył uczestnikom konferencji wytyczne opracowane przez władze pruskie w 1817 r. w kwestii przedstawiania człowieka w pisarstwie historycznym.

Kolejny cykl referatów przebiegał pod hasłem imago regis. Rozpoczął dr Jacek Wrzesiński (MPP Lednica) wykładem na temat rozwoju osadnictwa w poczatkach państwa polskiego, następnie dr Jaroslaw Dudek (Zielona Góra) zwrócił uwagę zebranych na burzliwe dzieje polityczne cesarstwa bizantyjskiego po wygaśnięciu dynastii macedońskiej w referacie poświęconym Michałowi VII Dukasowi. Dr Janina Gilewska-Dubis (Wrocław) przeanalizowała cechy charakterów średniowiecznych wiadców Polski na podstawie opisów „Kroniki Wielkopolskiej”, a mgr Katarzyna Skrzyńska (Warszawa) poszukiwała śladów pobytu w Drohiczynie Daniela Halickiego. W kolejnym wystapieniu mgr Agnieszka Kuś (Warszawa) skupiła się na rachunkach dworów, pokazujacych cechy charakteru władcy, a kończacy ten cykl referat dr Aleksandry Skrzypietz (Katowice) poświęcony został portretowi idealnego kandydata do tronu polskiego zawartemu $w$ pismach politycznych $z$ lat 1696 - 1697.

Ostatni cykl prelekcji pierwszego dnia obrad poświęcono obrazowi człowieka w źródlach historycznych (Picturae hominum). Mgr Marketa Dlouha (Praga) zaprezentowała referat pt.: „Ad imaginem hominis. Rytir a jeho barvy - heraldicka symbolika v literature ceskeho stredoveku". Kolejnym referentem był prof. Bogdan Rok (Wrocław), który przedstawił portret polskiego podróżnika XVIII w., zajmując się głównie podróżami edukacyjnymi. Następnie dr Maciej Kucharski (Katowice) zaprezentował tematykę pamiętnikarstwa epoki stanisławowskiej, a kończący obrady referat dr Dariusza Nawrota (Katowice) omówił postawy Litwinów w czasie wojny 1812 r. na podstawie źródeł urzędowych. Dzień intensywnych obrad zakończyla owocna dyskusja, której wątki kontynuowano podczas ogniska.

Obradom drugiego dnia przewodniczył prof. Antoni Barciak (Katowice). Inauguracyjny referat dr Adama Krawca (Poznań) dotyczył ciekawości świata człowieka średniowiecznego. Tematyka kolejnych wystapień oscylowała wokół religijności, sztuki i życia codziennego. Prof. Krzysztof Wachowski (Wrocław) zajał się problematyka pielgrzymek pokutnych w świetle badań archeologicznych, natomiast dr Jakub Kostowski (Wrocław) przybliżył słuchaczom temat średniowiecznych ołtarzy wrocławskich. Różnego sposobu wykorzystywania wiedzy przez ludzi średniowiecza i metod nauczania dotyczył referat dr Jacka Soszyńskiego (Warszawa). Z kolei dziejami pisma w okresie karolińskim zajał się dr Dariusz Sikorski (Poznań). Kolejne referaty skoncentrowały uwage słuchaczy na problematyce ksiag sądowych i metod poszukiwania w nich materiału do analizy życia codziennego (prof. Grzegorz Jawor i mgr Małgorzata Kołacz - UMCS Lublin). „Życie codzienne poprzez świadectwa kultury materialnej. Przykład późnośredniowiecznych joannitów śląskich" to natomiast tytuł referatu mgr Roberta Hesia (Muzeum Narodowe Wrocław).

Kolejna grupa referatów dotyczyła rodziny, dziecka i wychowania. Cykl referatów rozpoczęło wystapienie prof. Doroty Żołądź-Strzelczyk (Poznań) na temat stosunków rodzinnych w Polsce XVI-XVII w. Mówczyni wskazała na możliwości wykorzystania różnorodnych źródeł z tego okresu (traktatów pedagogicznych, pamiętników, źródeł epistolograficznych, testamentów, nagrobków itp.). Z kolei dr Krzysztof Ratajczak (Poznań) przedstawił możliwości źródłowe i perspektywy badań nad dziejami edukacji kobiet w Polsce średniowiecznej. Dwa następne referaty również dotyczyly dziejów kobiet: mgr Marzena Matla-Kozłowska (Poznań) zajęła się analiza obrazu kobiety we wczesnośredniowiecznych rocznikach polskich i czeskich, a dr Małgorzata Delimata (Poznań) zaprezentowała prelekcje na temat "Mulieres suspectae - przypadki niewiemych żon w aktach sądów kościelnych". 
Ostatni cykl wystapień dotyczył relacji człowiek - społeczeństwo w jej różnych aspektach. Obradom przewodniczył prof. Stanisław Suchodolski (Warszawa). Rozpoczał dr Przemysław Wiszewski (Wrocław) referatem dotyczacym poczatków tradycji rodowej Piastów, później dr Wojciech Mrozowicz (Wrocław) zajał się architektura kościoła zamkowego w Oleśnicy. Dalsze wystapienia dotyczyly wielkich rodów szlacheckich i mechanizmów ich społecznego awansu: dr Filip Wolański (Wrocław), dr Dariusz Rolnik (Katowice) oraz mgr Igor Wypijewski (Wroclaw). Mentalnością i stosunkami społecznymi wśród ludności normańskiej w XI w. zajął się mgr Przemysław Kulesza (Wrocław). Prof. Antoni Barciak (Katowice) przedstawił skład spoleczny średniowiecznego bractwa Najświętszej Marii Panny w Raciborzu, dr Iwona Pieprzyk (Katowice) i mgr Marcin Marcin Pauk (Warszawa) przybliżyli zagadnienia związane z czeskim spoleczeństwem doby Przemyślidów, a mgr Michał Gronowski OSB (Tyniec) dokonał prezentacji społeczności klasztoru tynieckiego w XVI-XVIII w. w świetle księgi profesyjnej. Relacje między szlachta a chłopami znalazły odzwierciedlenie w tekstach wystąpień dr Piotra Badyna i mgr Pawla Klinta (Wrocław), kończących drugi dzień obrad.

Ostatni dzień konferencji rozpoczął się od dyskusji nad referatami oraz podsumowaníem dokonań naukowych sympozjum, którego dokonal prof. Jerzy Strzelczyk (Poznań). Zorganizowano ponadto wyjazdy turystyczne na zamek w Zagórzu i zwiedzanie podziemi w Osówku. Podkreślić należy znakomita organizacje i atmosferę towarzysząca obradom i merytorycznym dyskusjom, w których uczestniczyło kilkudziesięciu uczonych z czołowych ośrodków akademickich kraju - specjalistów z dziedziny historii, historii sztuki, archeologii, źródloznawców, etnologów, geografów, socjologów i kulturoznawców.

Krzysztof Ratajczak

\section{Ogólnopolski Zjazd Peadgogiczny Polskiego Towarzystwa Pedagogicznego (Wrocław, 23 - 25 września 2004)}

We wskazanych powyżej dniach odbył się kolejny, V Zjazd PTP, którego organizację Towarzystwo powierzyło Dolnośląskiej Szkole Wyższej Edukacji TWP we Wrocławiu. W Zjeździe wzięło udział ponad 560 uczestników (zarówno teoretyków i badaczy edukacji, jak i wielu praktyków wychowania). Jak zawsze - choć w skromniejszej liczbie - w Zjeździe uczestniczyli również historycy wychowania. Swój udział zaznaczyli oni przede wszystkim w piątej tematycznej Sekcji Zjazdu - „Teraźniejszość w dialogu z edukacyjna przeszłościa". Obradami w sekcji kierowali prof. Jerzy Semków i prof. Sławomir Sztobryn.

O znaczeniu refleksji historycznej w pedagogice mówił w Sekcji m.in. S. Sztobryn. Swoim wystapieniem dokonał on swoistego wprowadzenia do dyskusji na temat aktualnego stanu, dorobku i statusu metodologicznego historii wychowania. Duże ożywienie w dyskusji wywołały jednak przede wszystkim treści referatu Gościa Sekcji - prof. Teresy Hejnickiej-Bezwińskiej.

Wiesław Jamrozek 